\title{
Mary Shelley's milieu, brought to life
}

\author{
The Lady and Her Monsters: A Tale of \\ Dissections, Real-Life Dr. Frankensteins, \\ and the Creation of Mary Shelley's \\ Masterpiece \\ Roseanne Montillo \\ HarperCollins; 2013
}

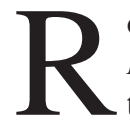

oseanne Montillo's The Lady and Her Monsters tells two tales: one interesting and fresh, the other a rehash of better biographical offerings. Mary Shelley was a young literary prodigy, wife of renowned poet Percy Bysshe Shelley and author of Frankenstein; or, the Modern Prometheus. Montillo ex plores Shelley's life story, the social and scientific milieu in which she grew up, and the wellspring of her creative urges.

Mary was the issue of a famous late 18th-century power couple. Her father, Charles Godwin, was an author and political philosopher. Her mother, writer Mary Wollstonecraft, died because of a retained placental fragment and subsequent sepsis two weeks after Mary's delivery.

Montillo, an American professor of literature, recalls Godwin's Sunday afternoon salon meetings of some of the most famous intellectuals of the day: poets Samuel Taylor Coleridge and William Wordsworth, the essayist Charles Lamb and scientist Humphry Davy, who not only dabbled in the effects of inhaling nitrous oxide but, more importantly (at least for this book), explored the chemistry of life, the concept of vitalism and the effect of the newly discovered force of galvanism on both living and dead tissues. Mary listened in, and the rest is history.

After electricity was characterized scientifically, early in the 17 th century, experiments were carried out in which this mysterious force was used in efforts to reanimate the dead - first frogs, then humans. It was thought that electricity was, or was part of, the "vital

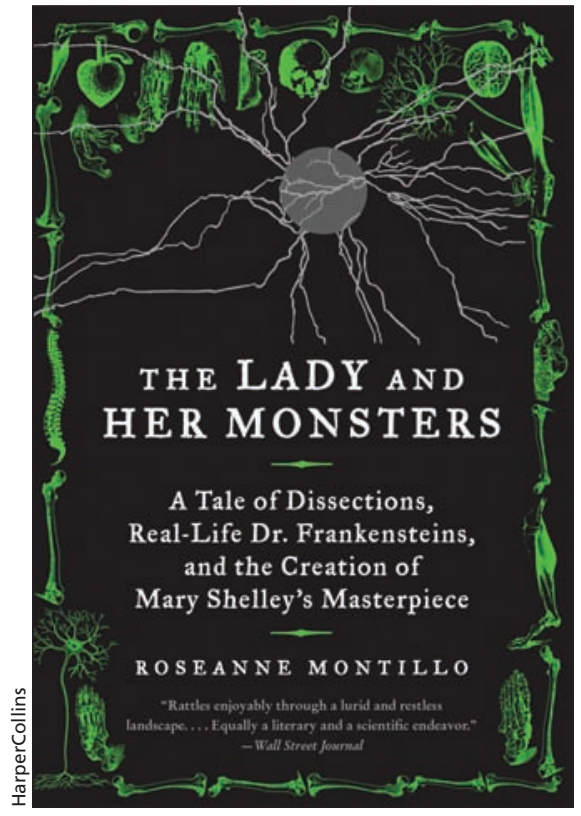

force" that made up life; whoever mastered it would hold the key, not only to reviving the dead but perhaps even to creating life.

Beyond describing this milieu, Montillo explains how it was ultimately acknowledged that Mary Shelley, rather than her then more accomplished husband, who actually authored the book - a fine twist of irony given her mother's pioneering feminist bona fides.

Like Dr. Frankenstein bringing life to dead flesh, Montillo tries to galvanize her readers. Unfortunately, she only partly succeeds. While the particular recounting of the social and scientific context in which Frankenstein was written is what this book does best, the story could have been recounted in a medium-length magazine article. That being said, I am now better acquainted with the creative processes that went into Shelley's masterpiece.

\section{A. Mark Clarfield MD \\ Department of Geriatrics Soroka Hospital and Ben-Gurion University of the Negev Beersheba, Israel}

CMAJ 2014. DOI:10.1503/cmaj.131388 